\title{
Breeding population of Black Stork, Ciconia nigra, in Italy between 1994 and 2016
}

\author{
Maurizio Fraissinet*, Lucio Bordignon, Massimo Brunelli, Matteo \\ Caldarella, Enzo Cripezzi, Stefano Giustino, Egidio Mallia, Maurizio \\ Marrese, Nicola Norante, Salvatore Urso, Matteo Visceglia
}

\begin{abstract}
The Black Stork Ciconia nigra, following an expansion on European scale, started breeding in Italy in 1994 with one pair in the Piedmont Region and one in the Calabria Region. Since then, the breeding pairs established in Italy have progressively increased up to 18 in 2016, and they are currently in Piedmont, Lazio, Campania, Molise, Apulia, Basilicata and Calabria. However, the number of breeding pairs could be higher than 20 , as indicated by records and observations of adults and juveniles, during the breeding period in potentially suitable nesting areas. Despite the low population density in Italy, the trend in the breeding population in Northwest and in Southern Central regions seems to show a slight and high increase respectively. Productivity, breeding success and fledging rate have been considered and analysed. A difference between the two macro areas has been found in the choice of nesting sites, which is on trees for Northwest couples, and cliffs for Southern Central couples. It is necessary to further explore the reason why the small Northwest population does not show any increase and range expansion compared to the Southern Central one.
\end{abstract}

Key words: Ciconia nigra, Italy, monitoring, breeding biology, trend, nest site selection.

Riassunto - La popolazione di Cicogna nera, Ciconia nigra, nidificante in Italia nel periodo 1994-2016.

La Cicogna nera Ciconia nigra, in seguito ad un fenomeno di espansione su scala europea, ha iniziato a nidificare in Italia nel 1994 con una coppia in Piemonte ed una in Calabria. Da allora le coppie nidificanti accertate in Italia sono progressivamente aumentate fino a 18 nel 2016, distribuite in: Piemonte, Lazio, Campania, Molise, Puglia, Basilicata e Calabria. Tuttavia diverse segnalazioni ed osservazioni in periodo riproduttivo di adulti e giovani in aree potenzialmente idonee alla nidificazione della specie, lasciano ipotizzare un numero di coppie nidificanti superiore a 20 . Nonostante la consistenza della popolazione sia complessivamente bassa, l'andamento delle popolazioni nidificanti nell' Italia nord-occidentale e centro-meridionale mostrano, rispettivamente, un incremento moderato e un forte incremento. Sono state

G.L.I.Ci.Ne. (Gruppo di Lavoro Italiano sulla Cicogna Nera), Via Vioglio 16, 13834 Soprana (BI), Italia.

* Corresponding author: mfraissinet@tiscali.it

(C) 2018 Maurizio Fraissinet, Lucio Bordignon, Massimo Brunelli, Matteo Caldarella, Enzo Cripezzi, Stefano Giustino, Egidio Mallia, Maurizio Marrese, Nicola Norante, Salvatore Urso, Matteo Visceglia

Received: 1 June 2017

Accepted for publication: 13 September 2018 approfondite la produttività, il successo riproduttivo e il tasso di involo. Una differenza tra le due macro aree si riscontra nella scelta del sito di nidificazione, su albero per le coppie del Nord-Ovest e su roccia per quelle del Centro-Sud. Da approfondire il motivo per cui la piccola popolazione nord-occidentale non mostra segni di crescita e di espansione geografica rispetto a quella dell'Italia centro-meridionale.

Parole chiave: Ciconia nigra, Italia, monitoraggio, biologia riproduttiva, andamenti, selezione dei siti per la nidificazione.

\section{INTRODUCTION}

The Black Stork Ciconia nigra has the largest breeding range among the Ciconiidae, which goes from Portugal to China, with a distinct population in South Africa (del Hoyo et al., 1992), and a world population estimated around 32,000-44,000 individuals (AEWA, 2013). The breeding population in Europe is currently estimated to be around 9,800-13,900 couples and classified as Least Concern (BirdLife International, 2015). After the strong decrease occurred during the XIX century and in the first decades of the XX century, the European population has been increasing in the last decades, especially in several countries of Central Europe where extinction occurred in the past, due to uncontrolled hunting and excessive forest exploitation (Cramp \& Simmons, 1977). The positive trend of the population coincided with the decades '70, ' 80 and ' 90 , with the colonization of several countries, among which Italy, and further increase of the populations of Central Europe (del Hoyo et al., 1992; Dornbusch \& Dornbusch, 1996; Horman \& Richarz, 1996; Hormann, 1999; Snow \& Perrins, 1998; BirdLife International, 2004; 2015; Alexandrou et al., 2016). Even if in Italy there is no documented evidence of its historical presence as a breeding species (Boano, 1992), it is likely that the process of colonization is not a new one, but a return of the species dating back to the XIV - XV centuries. Subsequently, starting from the XIX century, reports of the species essentially refer to killed and collected specimens or specimens observed during migration (Bordignon, 2005; Bordignon et al., 2006).

In Italy, the first breeding attempts were established in 1994 in Piedmont and Calabria (Bordignon 1995; Mordente et al. 1998). The colonization continued with an increase in the number of couples and a breeding range expansion, which currently regards Basilicata, Apulia, Campania, 
Lazio and Molise (Bordignon, 1999; 2005; Bordignon et al., 2003; 2006; 2007). In 2002 and 2003 there have also been some nesting attempts in Lombardy, but there has not been any laying of eggs (Bordignon et al., 2009).

In order to monitor the presence of the species in each region and to follow the colonization and study its reproductive biology, in 2003 an ornithological workgroup was created, which is called G.L.I.Ci.Ne. (Gruppo di Lavoro Italiano sulla Cicogna Nera). This group has been monitoring the breeding pairs every year and therefore has acquired data in Italy, with regard to the chronological evolution and the reproductive biology of the species. The purpose of this research is to provide an update about the population of Black Stork breeding in Italy, contributing to add information about the species in Europe and supporting conservation policies at the national scale. These issues have been addressed by looking more deeply at the numerical trend of the two Italian populations, their productivity, breeding success and fledging rates.

\section{MATERIALS AND METHODS}

Following the evidence of the first nesting pairs in Piedmont and Calabria, the G.L.I.Ci.Ne. monitored the suitable sites for the species with the support of local ornithologists. The records of nests or individuals with breeding behaviours (transport of material for nest construction, courtship, constant attendance of a couple in a site, etc.) led to a deepening by the regional coordinators. Therefore, the nesting detection led to a nest monitoring with periodic but constant visits, spread over time to avoid disturbance.

The observations at the nests were made from a safe distance using telescopes up to $60 \mathrm{x}$ in order to avoid disturbing the breeding pairs. The visitation frequency varied according to the availability of observers; in any case, visits were made during the breeding season - mid March/ early August (Brichetti \& Fracasso, 2003; Bordignon, 2005 ) - when it was possible to collect data on the deposition, the number of nestlings and the number of fledged juveniles. The reproductive parameters, like productivity (fledged juveniles/territorial pairs), breeding success (fledged juveniles/pairs having laid eggs) and fledging rate (fledged juveniles/pairs having bred nestlings), refer to Cheylan (1981). The trends of time series have been calculated using TRIM software (Pannekoek \& Van Strien, 2013). The difference between the averages has been verified using the Student t-test.

\section{RESULTS}

In the period 1994-2016 a number of 179 found nesting has been counted in Italy (average 7.7, st. dev. 4.7; range 2-18 pairs) which have led overall to the fledging of 414 juveniles (Tab. 1).

The colonization started contemporarily in two different regions, Piedmont and Calabria, situated respectively in the North and South of Italy. The two couples from Piedmont started breeding on trees, while the couple from Calabria started breeding on cliffs. Since then, the Northwest couples have always been breeding on trees, while the Southern Central couples have been breeding on cliffs (Figs. 1 and 2). A breeding-site fidelity has also been observed, with changes over the years of nesting site of a few tens of meters, confirming what is already known from the literature (cfr Strazds, 2011; Strenna et al., 2016).

In the considered period $75.4 \%$ of the couples established on the territory have been reproducing. Fig. 3 shows the breeding range updated to 2016.

The number of breeding pairs has been increasing over the years (Fig. 4). After a first period of swinging, starting from the year 2000 there has been a strong increase in the whole of Italy and in Southern Central Italy; since 2002 there has been a moderate increase in Northwest Italy. The TRIM analysis shows a continuing increase, with a high increase $(\mathrm{P}<0.01$; average rate: $0.088 \pm 0.006)$ for all Italy, a high increase $(\mathrm{P}<0.01$; average rate: $0.123 \pm 0006)$ for Southern Central Italy and a slight increase $(\mathrm{P}<0.05$, average rate: $0.027 \pm 0.011)$ for Northwest Italy.

In Tab. 2 the overall reproductive parameters for Italy are summarized and classified on the basis of the two different geographical areas.

The comparison between the average productivity of the couples of Northwest Italy and Southern Central Italy does not show a significant difference between the two average values $(\mathrm{t}=1.35, \mathrm{P}=0.19)$.

The overall trend in productivity within the period 1994-2016 (Fig. 5) grew over the years compared with the average value, after a start with rather low values. The overall trends in breeding success and fledging rate (Figs. 6 and 7) almost overlap: they also show an initial period with low values, followed by a value increase in subsequent years and a stable adjustment with very noticeable periodic oscillations of about 5 years.

The values of the reproductive parameters are in line with the evidence found in other European populations (Tab. 3).

\section{DISCUSSION AND CONCLUSIONS}

The Black Stork, after a very long period of absence, has returned breeding in Italy following an expansion phenomenon of the species regarding Central and Southern Europe (BirdLife International, 2004; 2015). The first couples have been observed in two regions contemporarily: Piedmont (Northwest Italy) and Calabria (Southern Italy). From the first 3 couples found in 1994 (however nesting could have started earlier without being detected) we go up to 18 couples in 2016. To these, additional 3-4 couples should be added but nesting has not been verified yet.

These couples are located in Campania, Molise and Apulia, but the nests have not been found so far, therefore they cannot be defined as nesting pairs. As the species is quite elusive, it is not always easy to find the nest, especially in impassable areas. Similar situations are also found in other European countries (Zielinski et al., 2011; Gendre et al., 2014; Pojer \& Vo Itechovska, 2016). The process of growth seems to be in line with that of other European countries, however showing a very low increase in Northwest couples compared to the high increase in Southern Central couples (Fig. 4). In several 
Tab. 1 - Numbers of breeding pairs and fledged juveniles in Italy during the period 1994-2016. / Coppie nidificanti e giovani involati in Italia nel periodo 1994-2016.

a) territorial pairs / coppie territoriali; b) pairs having laid eggs / coppie che hanno deposto uova; c) pairs having bred nesting / coppie che hanno allevato la nidiata; d) fledged juveniles / giovani involati.

\begin{tabular}{|c|c|c|c|c|c|c|c|c|c|c|c|c|c|c|c|c|c|c|c|c|c|c|c|c|c|c|c|c|c|c|c|c|c|c|c|c|}
\hline \multirow[t]{2}{*}{ Year } & \multicolumn{4}{|c|}{ Piedmont } & \multicolumn{4}{|c|}{ Lombardy } & \multicolumn{4}{|c|}{ Lazio } & \multicolumn{4}{|c|}{ Campania } & \multicolumn{4}{|c|}{ Molise } & \multicolumn{4}{|c|}{ Apulia } & \multicolumn{4}{|c|}{ Basilicata } & \multicolumn{4}{|c|}{ Calabria } & \multicolumn{4}{|c|}{ ITALY } \\
\hline & $\mathbf{a}$ & $\mathbf{b}$ & c & d & a & b & c & d & a & b & c & d & $\mathbf{a}$ & b & c & d & a & $\mathbf{b}$ & c & d & a & $\mathbf{b}$ & c & d & $\mathbf{a}$ & $\mathbf{b}$ & c & d & a & b & c & d & a & b & c & d \\
\hline 1994 & 2 & 1 & 1 & 4 & & & & & & & & & & & & & & & & & & & & & & & & & 1 & 1 & 1 & 4 & 3 & 2 & 2 & 8 \\
\hline 1996 & 2 & 2 & 2 & 4 & & & & & & & & & & & & & & & & & & & & & & & & & & & & & 2 & 2 & 2 & 4 \\
\hline 1997 & 3 & 1 & 1 & 4 & & & & & & & & & & & & & & & & & & & & & & & & & 1 & 1 & 1 & 2 & 4 & 2 & 2 & 6 \\
\hline 1998 & 2 & 1 & 1 & 3 & & & & & & & & & & & & & & & & & & & & & & & & & & & & & 2 & 1 & 1 & 3 \\
\hline 2000 & 3 & 0 & 0 & 0 & & & & & & & & & & & & & & & & & & & & & 1 & 1 & 1 & 4 & 1 & 1 & 1 & 4 & 5 & 2 & 2 & 8 \\
\hline 2001 & 3 & 1 & 1 & 3 & & & & & & & & & & & & & & & & & & & & & 1 & 0 & 0 & 0 & 2 & 1 & 1 & 4 & 6 & 2 & 2 & 7 \\
\hline 2002 & 1 & 0 & 0 & 0 & & & & & 1 & 0 & 0 & 0 & & & & & & & & & & & & & 2 & 2 & 2 & 6 & & & & & 4 & 2 & 2 & 6 \\
\hline 2003 & 2 & 2 & 2 & 6 & & & & & 1 & 0 & 0 & 0 & & & & & & & & & & & & & 2 & 1 & 1 & 3 & & & & & 5 & 3 & 3 & 9 \\
\hline 2004 & 2 & 1 & 1 & 4 & & & & & & & & & & & & & & & & & & & & & 2 & 2 & 2 & 7 & & & & & 4 & 3 & 3 & 11 \\
\hline 2008 & 3 & 3 & 3 & 8 & 1 & 0 & 0 & 0 & & & & & & & & & & & & & & & & & 4 & 4 & 4 & 12 & & & & & 8 & 7 & 7 & 20 \\
\hline 2009 & 3 & 3 & 3 & 11 & 1 & 0 & 0 & 0 & & & & & 1 & 1 & 1 & 2 & & & & & & & & & 5 & 4 & 4 & 15 & & & & & 10 & 8 & 8 & 28 \\
\hline 2010 & 3 & 3 & 3 & 11 & & & & & & & & & 1 & 1 & 1 & 4 & & & & & & & & & 6 & 5 & 5 & 16 & & & & & 10 & 9 & 9 & 31 \\
\hline 2011 & 3 & 3 & 3 & 9 & & & & & & & & & 1 & 1 & 1 & 3 & & & & & & & & & 6 & 5 & 5 & 16 & & & & & 10 & 9 & 9 & 28 \\
\hline 2012 & 3 & 3 & 3 & 8 & & & & & & & & & 1 & 1 & 1 & 2 & & & & & 2 & 2 & 2 & 8 & 6 & 6 & 6 & 17 & & & & & 12 & 12 & 12 & 35 \\
\hline 2013 & 4 & 3 & 3 & 6 & & & & & & & & & 1 & 1 & 1 & 3 & & & & & 2 & 1 & 1 & 2 & 6 & 4 & 4 & 14 & & & & & 13 & 9 & 9 & 25 \\
\hline 2014 & 4 & 4 & 4 & 11 & & & & & 1 & 1 & 1 & 3 & 1 & 1 & 1 & 2 & & & & & 2 & 0 & 0 & 0 & 7 & 6 & 5 & 18 & & & & & 15 & 12 & 11 & 34 \\
\hline 2015 & 4 & 3 & 3 & 9 & & & & & 1 & 1 & 1 & 4 & 1 & 1 & 1 & 3 & & & & & 2 & 2 & 2 & 8 & 8 & 8 & 8 & 22 & 1 & 1 & 1 & 2 & 17 & 16 & 16 & 48 \\
\hline 2016 & 4 & 3 & 3 & 10 & & & & & 1 & 1 & 1 & 4 & 1 & 1 & 1 & 2 & 1 & 1 & 0 & 0 & 2 & 2 & 2 & 8 & 8 & 7 & 6 & 19 & 1 & 1 & 1 & 4 & 18 & 16 & 14 & 47 \\
\hline
\end{tabular}

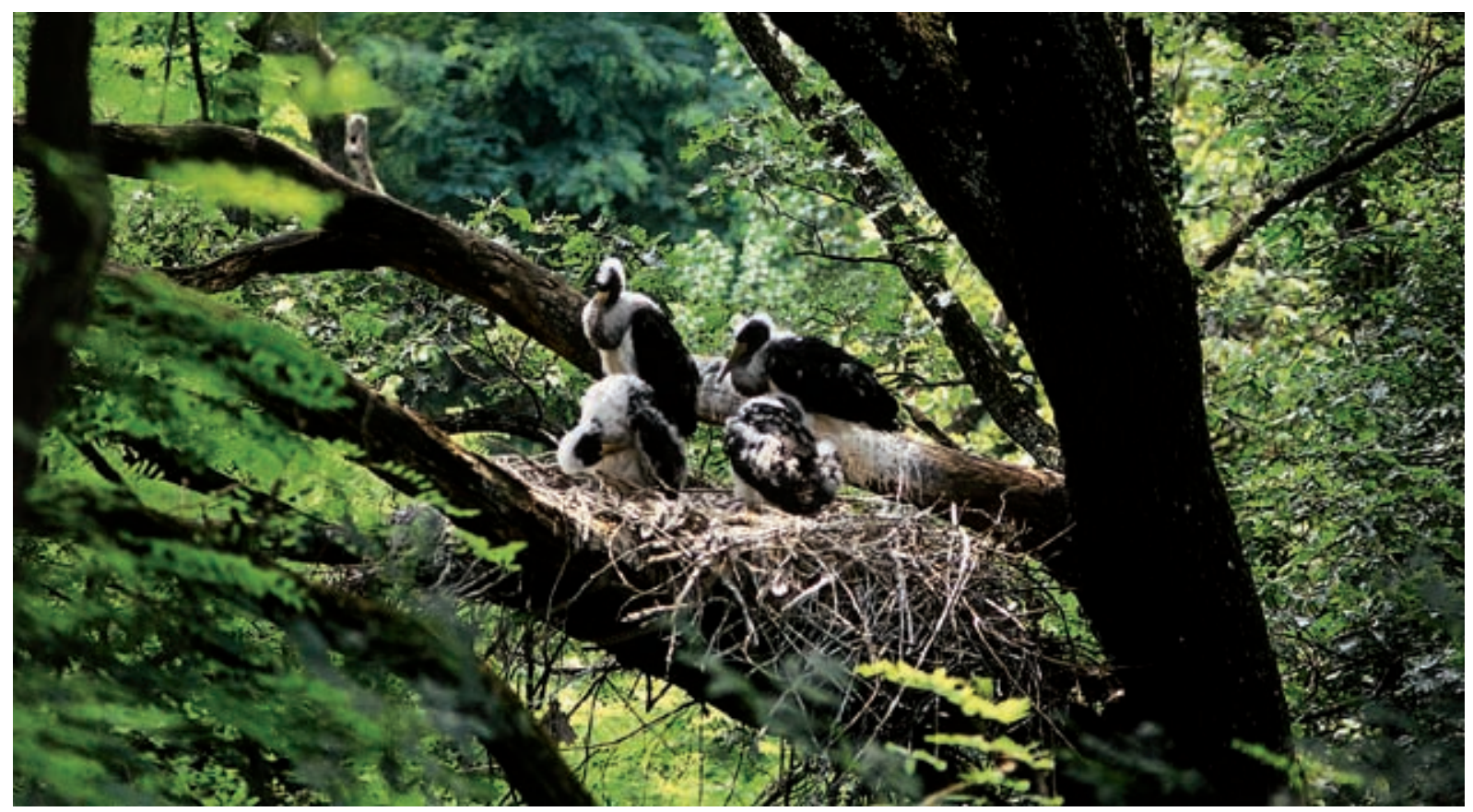

Fig. 1 - Nest on the tree in Northwest Italy. / Nido su albero in Italia nordoccidentale. (Foto / Photo Giorgio Turri). 


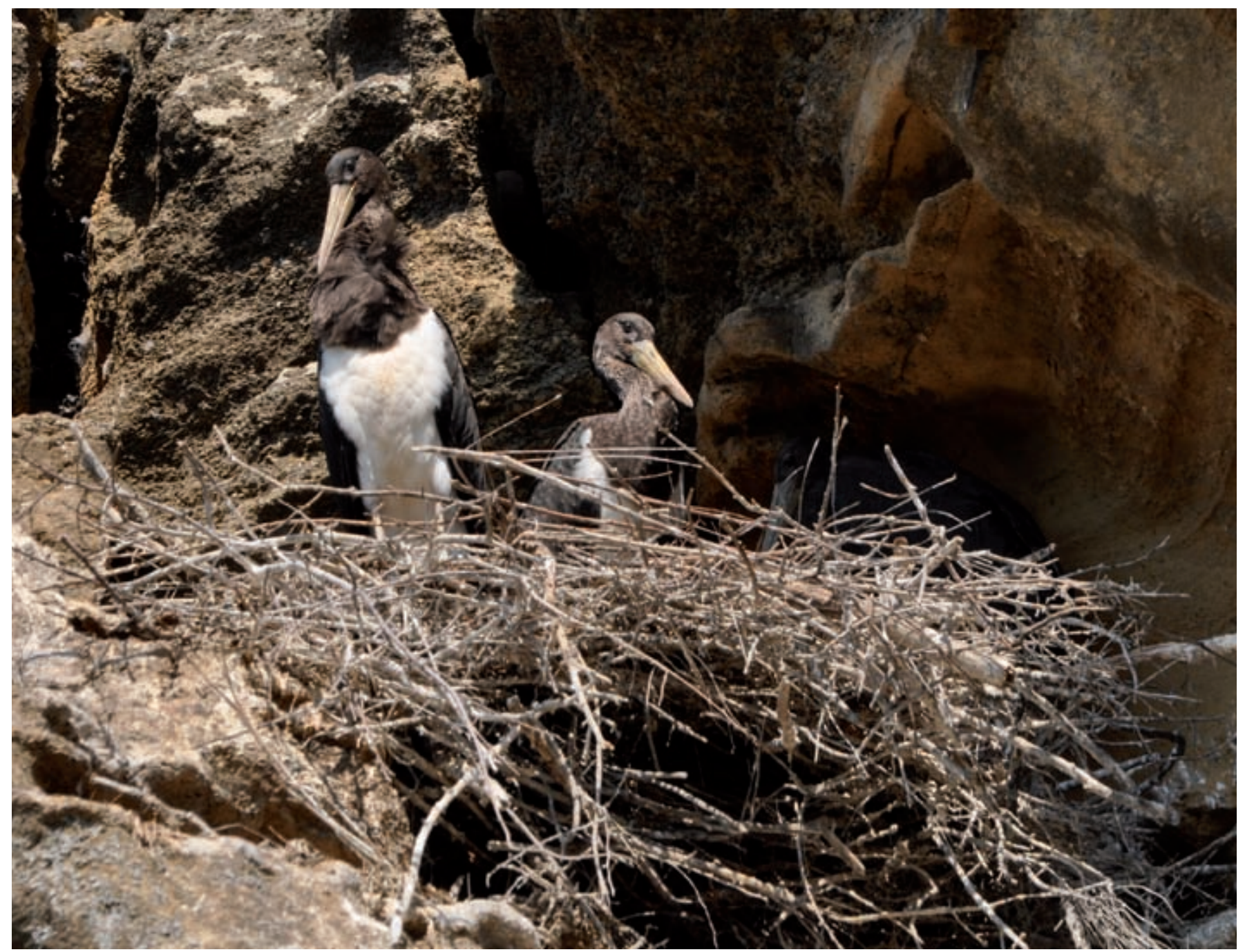

Fig. 2 - Nest on the cliff in Southern Italy. / Nido su parete rocciosa in Italia meridionale. (Foto / Photo Maurizio Fraissinet).
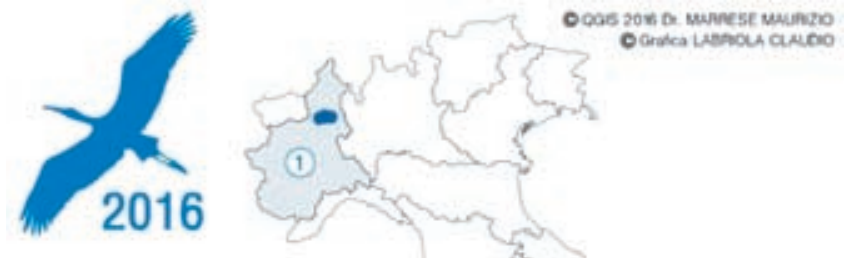

(1) Piedmont 4

(2) Lazio 1

(3) Campania 1

(4) Molise 1

(5) Apulia 2

(6) Basilicata 8

(7) Calabria 1

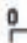
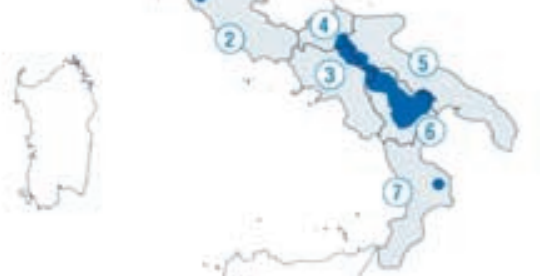

800

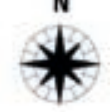

Fig. 3 - Breeding range updated to 2016. / - Areale riproduttivo aggiornato al 2016
European countries, both western and eastern, there is an increase in Black Stork number. Significant increases are registered in Luxembourg, Hungary, Poland and Ukraine. Increases are also recorded in France, Germany and the Czech Republic (Dzyubenko \& Bokotey, 2011; BirdLife International, 2015; Kalocsa \& Tamas, 2016; Lorge, 2016; Denis \& Brossault, 2016; Pojr \& Vo Itechovska, 2016). However, in none of these countries, although there are rapid and significant increases in the number of couples (in some cases considerably faster and more substantial than those recorded in Italy), there are literature data about trend analysis by statistical methods. A decrease is reported in the Baltic countries (Sellis, 2000; Strazds, 2011; BirdLife International, 2015) and is attributed to the strong disruption of excavation work in forest areas. Another interesting comparative aspect is relative to the number of couples which manage to have fledged juveniles; it is equal to $97.8 \%$ in Italy (present work), similar to $97.3 \%$ found in France (Gendre, et al., 2014), but it is between $23 \%$ and $40 \%$ in Belarus and between $39.6 \%$ and $74.6 \%$ in Latvia (Strazds, 2011). Such low values are due to both anthropic disturbances caused by forestry work and predation (Strazds, 2011). Both of these factors were 


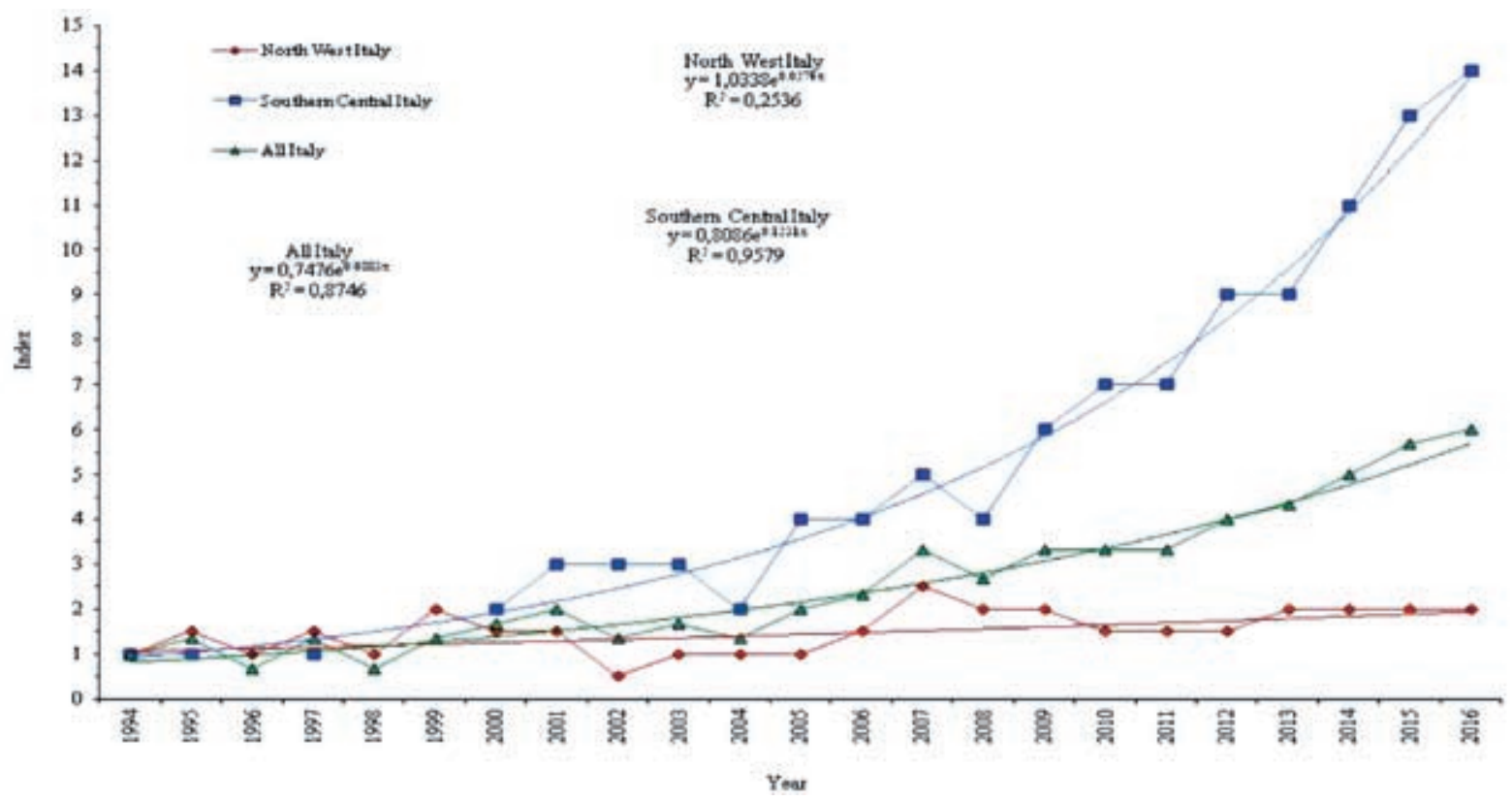

Fig. 4 - Comparison of trends in the number of breeding pairs. / Confronto tra gli andamenti del numero di coppie nidificanti.

Tab. 2 - Reproductive parameters of the Black Stork population breeding in Italy during the period 1994-2016. The letters refer to the legend of Tab. 1. NW) North-West, SC) Southern Central. / Parametri riproduttivi della Cicogna nera nidificante in Italia nel periodo 1994-2016. Le lettere si riferiscono alla legenda della Tab. 1. NW) Nord-Ovest, SC) Centro-Meridionale.

\begin{tabular}{|c|c|c|c|}
\hline Parameters & NW & SC & Italy \\
\hline Territorial pairs (a) & 70 & 109 & 179 \\
\hline Pairs having laid eggs (b) & $45(64.3 \%)$ & $90(82.6 \%)$ & $135(75.4 \%)$ \\
\hline Pairs having bred nestlings (c) & $45(100 \%)$ & $87(96.7 \%)$ & $132(97.8 \%)$ \\
\hline Fledged juveniles (d) & 133 & 277 & 414 \\
\hline Productivity (d/a) & 1.90 & 2.58 & 2.31 \\
\hline Breeding success $(\mathrm{d} / \mathrm{b})$ & 2.93 & 3.07 & 3.06 \\
\hline Fledging rate $(\mathrm{d} / \mathrm{c})$ & 2.95 & 3.18 & 3.13 \\
\hline
\end{tabular}

Tab. 3 - Data comparison of three reproductive parameters derived from the Present study and Bibliography. / Confronto dei dati relative a tre parametri riproduttivi ricavati dal presente studio e in bibliografia.

\begin{tabular}{|l|c|c|c|l|}
\hline Country & Productivity & Breeding success & Fledging rate & Source \\
\hline Italy & 2.31 & 3.06 & 3.13 & Present Study \\
\hline Northwest Italy & 1.90 & 2.93 & 2.95 & Present Study \\
\hline Southern Central Italy & 2.58 & 3.07 & 3.18 & Present Study \\
\hline Austria & & & 3.31 & von Puhringer, 2007 \\
\hline Belgium & & & 3.43 & Jadoul, 2001 in Janssen et al., 2004 \\
\hline Poland & 2.44 & 2.84 & Czuchnowski et al., 2003; Zielinski et al., 2011 \\
\hline Latvia & & & 3.29 & Strazds, 2011 \\
\hline Czech Republic & 2.66 & & 2.98 & Pojer, 2003 \\
\hline Spain (Madrid) & 2.53 & & Cano Alonso et al., 2003 \\
\hline Iberian Peninsula & 1.86 & & 3.60 & Kalocsa \& Tamas, 2003 \\
\hline Hungary & & & & Tamas, 2012 \\
\hline Hungary & 2.63 & & 3.17 & Jans \& Longe, 2003 \\
\hline Greece NE & 3.27 & & & \\
\hline Luxembourg & & & & \\
\hline
\end{tabular}




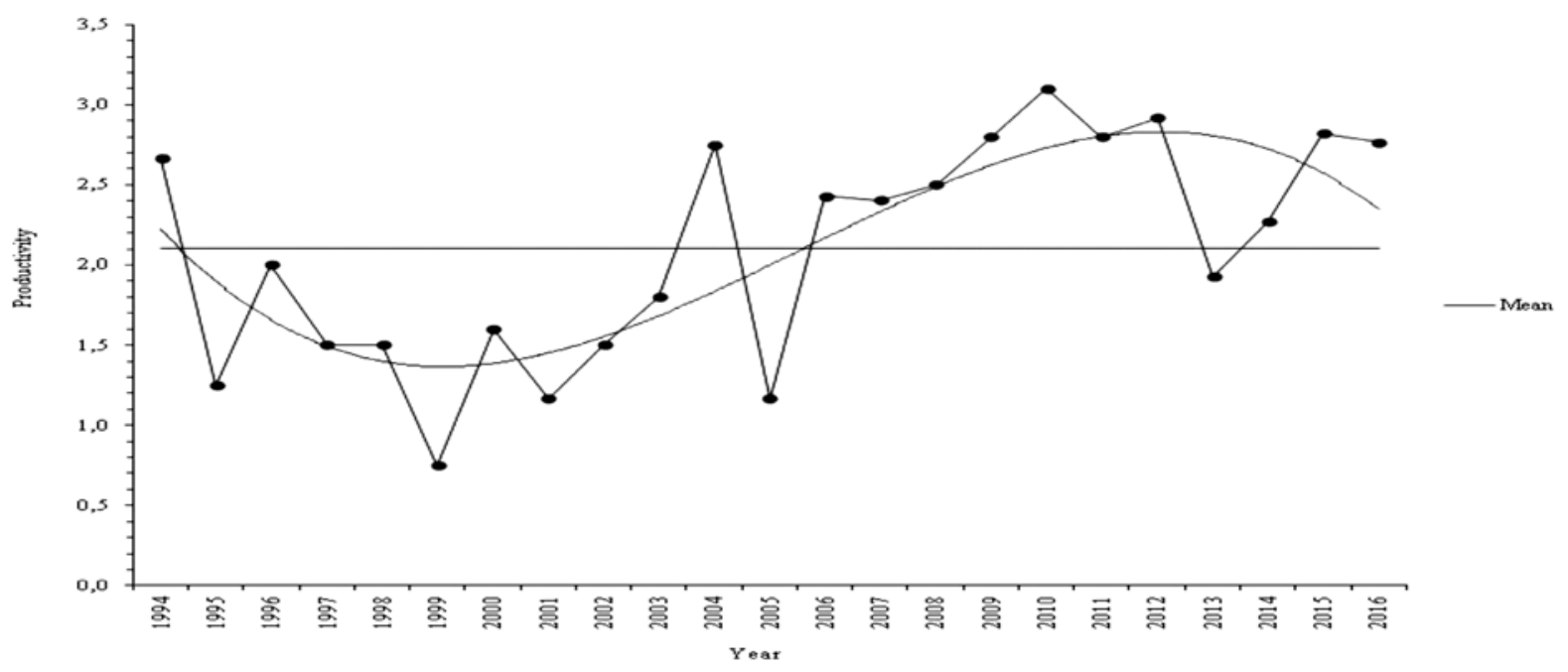

Fig. 5 - Trend in productivity. / Andamento della produttività.

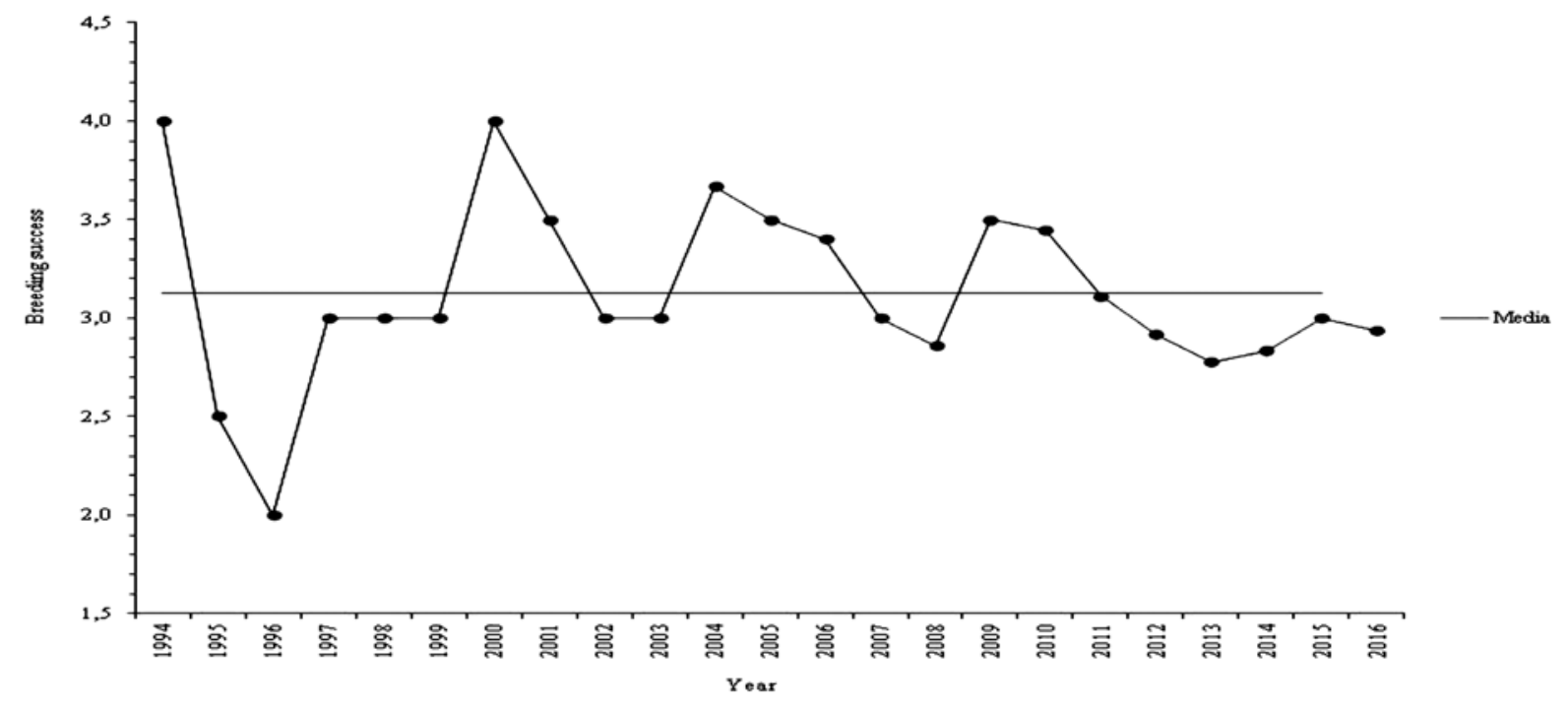

Fig. 6 - Trend in breeding success. / Andamento del successo riproduttivo.

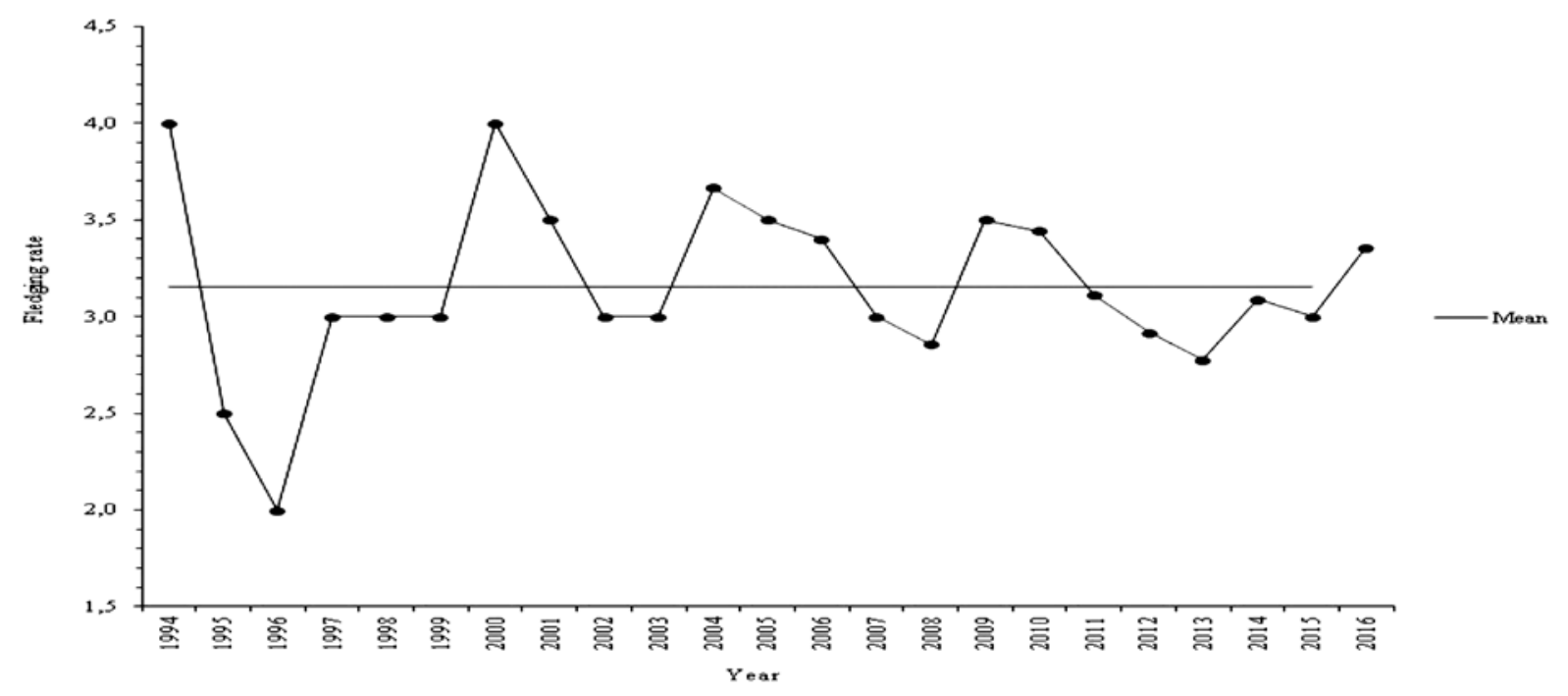

Fig. 7 - Trend in fledging rate. / Andamento del tasso di involo. 
not found in Italy during the present study; the three cases of failure were instead caused by free-climbers (Molise in 2016), death of an adult and its only juvenile for unchecked causes, however both of them were in the nest suggesting a poisoning case (Basilicata in 2014) and unknown causes (Basilicata in 2016).

The gathered data has shown that the increase of the Italian population is essentially due to the breeding population in Southern Central Italy.

A comparative analysis between the breeding couples in Northwest Italy and Southern Central Italy shows some differences. In the first place, there's a difference in the choice of the nesting site: trees for Northwest couples, cliffs for Southern couples; an intermediate situation occurred in the Lazio region, where the species, since the first nesting trials in 2002, have built one nest on cliff and two nests on a tree in a wide forest area, coming up to the current situation where we have a nest on a tree on the edge of a cliff (Brunelli et al., 2014).

Eastern Palearctic subpopulations nest very widely on cliffs and Southern Africa subpopulations nest exclusively on cliffs (cfr. Tamas, 2012; Cano Alonso, 2013); differently in Western Palearctic the nesting on cliffs is an exception and it is considered an adaptation due to the progressive deforestation of the last few centuries (Petkov, 2006; Tamas, 2012; Cano Alonso, 2013). Therefore, it can be assumed that the two groups of Black Stork breeding in Italy have different origins. The Northwestern group, breeding exclusively on trees, shows the typical situation of most Central European countries, while the Southern Central group, breeding exclusively on cliffs, might originally come from the mountain areas of East-Central Europe (Austria and Bulgaria), where a significant part of the population builds nests on cliffs (Petrov et al., 1995; Petkov et al., 2006; von Puhringer, 2007). Another difference is the diverse increase rate of breeding pairs, shown in Fig. 4, which is a further aspect to be explored. The Northwest population, 20 years after colonization, is not showing any increase and has not colonized the Central and Eastern part of the subalpine area and Po Valley. In particular, we should check the state of old-growth forests with trees suitable for the nesting of the species (Lohmus $\&$ Sellis, 2003), thus improving the efforts of field investigation in potentially suitable areas.

The small size of the breeding range, together with the scarce breeding population size, justify the classification of the species in the "Vulnerable" category, as included in the more recent Italian Red List (Peronace et al., 2012).

\section{Acknowledgements}

For the Lazio Region special thanks to Gianni Bombara, Stefano Celletti, Alessandro Montemaggiori, Roberto Papi, Guido Prola and Lorenzo Sestieri for the cooperation on the field.

For the Calabria Region special thanks to Dott. Francesco Lamanna who recorded the nesting in 2015, and to the associates of the Stazione Ornitologica Calabrese who keep on following the reproduction of the species: Eugenio Muscianese, Manuela Policastrese, Salvatore Salerno, Giuseppe Rocca, Marcello Longeri. For the Apulia Re- gion special thanks to Giuseppe Agnelli, Incoronata Brescia, Leonardo De Lullo, Filippo Silvestri, Vincenzo Rizzi and all the associates and volunteers of the CSN ONLUS, Antonio Dembech, Michele Ferro, Paolo Gattillo, Vittorio Giacoia, Antonio Lepore, Paola Lodeserto, Manuel Marra, Massimo Notarangelo, Ventura Talamo, Filomena Petruzzi, the other associates and activists of the LIPU Onlus and the LIPU Gravina oasis of Laterza. For Molise special thanks to Massimo Martusciello and Carlo Meo of the LIPU Onlus and Lorenzo de Lisio.

For the Campania Region special thanks to all the associates of ASOIM who collaborated to nesting monitoring over the years, Marcello Bruschini, Annamaria Cafieri, Silvia Capasso, Giuseppe Di Martino, Bruno Dovere, Elio Esse, Silvana Grimaldi, Danila Mastronardi, Giulia Mendone, Ivan Pagano, Stefano Piciocchi, Alessio Usai, Marilena Terminio, the people of Monteverde who have guaranteed safety for the unique nest of Campania; special thanks to all the officials and managers of Assessorato all'Ambiente della Regione Campania (Environmental Regional Ministry) for their measures and actions to protect the nest. For the Piedmont Region special thanks for their field research to all staff of Parco delle Riserve Pedemontane e Terre d'acqua, Parco della Valsesia, Parco della Valle del Ticino, security staff or Provincia di Biella, staff of the Comune Villa del Bosco, Corpo delle Guardie Ecologiche Volontarie, Corpo delle Guardie Volontarie Rangers di Italia, Biella, Pro Natura Biellese, WWF Biella, Lega Ambiente Biella, Accardi Antonio, Anselmetti Giorgio, Baietto Marco, Benedetto Franco, Bidesi Enzo, Bonagura Simone, Bragante Gianni, Bressa Claudio, Brunetti Giuseppe, Castello Alessandro, Compostella Chiara, Ferraris Giuseppe, Ferretti Gianluca, Fontaneto Claudia, Galiazzo Giorgio, Lorenzini Franco, Mancuso Emerico, Montorio Roberto, Montorsi Eugenio, Naborrini Carlo, Oddone Claudio, Orilia Carla e Marco, Pellissier Paolo, Ranghino Sandro, Ranotto Paolo, Sicurtà Franco, Stocchi Fulvio, Turri Piergiorgio, Mario Vietti, Vogesi Flavio, Manuel Zulato.

For the Basilicata Region, special thanks to Adriano Castelmezzano, Rocco Dambrosio, Antonio Dembech, Mariangela Francione, Egidio Fulco, Carlo Gilio, Andrea Maragno, Angelo Nitti, Filomena Petruzzi, Gianvito Santantonio, Antonio Sigismondi, Rocco Silvaggi. Special thanks to Centro Recupero Animali Selvatici della Riserva San Giuliano, Ente Parco Regionale di Gallipoli Cognato Piccole Dolomiti Lucane, Ente Parco Regionale della Murgia Materana, LIPU Basilicata e Puglia, Provincia di Matera, Ufficio Tutela della Natura della Regione Basilicata.

Thanks to Carmen and Silvia Capasso for the English translation and to Claudio Labriola for the graphic of figure 3.

Thanks to Marco Gustin and Paul Brossault for the rereading of the text and the suggestions.

\section{REFERENCES}

AEWA, 2013 - Black Stork Ciconia nigra. Poster in: $<$ www.unep-aewa.org >

Alexandrou O, Bakaloudis D. E., Papakosta M. A. \& Vlachos C. G., 2016 - Breeding density, spacing of nest-sites and breeding per- 
formance of black storks Ciconia nigra in Dadia-Lefkimi-Soufli Forest National Park, north-eastern Greece. North-Westernn Journal of Zoology, 12: 7-13.

BirdLife International, 2004 - Birds in Europe: population estimates, trends and conservation status. BirdLife Conservation Series, No 12, Cambridge.

BirdLife International, 2015 - European Red List of Birds. Office for Official Publications of the European Communities, Luxembourg.

Boano G., 1992 - Cicogna nera Ciconia nigra. In: Fauna d'Italy. XXIX. Aves. I. Brichetti et al. (eds). Edizioni Calderini, Bologna: 211-216.

Bordignon L., 1995 - Prima nidificazione della Cicogna nera, Ciconia nigra, in Italia. Rivista italiana di Ornitologia, 64: 106-116.

Bordignon L., 1999 - Nuove nidificazioni e recente espansione della Cicogna nera, Ciconia nigra, in Italia. Avocetta, 23: 99.

Bordignon L. (ed.), 2005 - La Cicogna nera in Italia. Parco Naturale del Monte Fenera. Tipolitografia di Borgosesia s.a.s, Borgosesia.

Bordignon L., Brunelli M., Francione M., Rocca G. \& Visceglia M., 2003 - Aggiornamento sulla riproduzione della Cicogna nera, Ciconia nigra, in Italia. Rivista italiana di Ornitologia, 73: 168171.

Bordignon L., Brunelli M. \& Visceglia M., 2006 - La cicogna nera Ciconia nigra in Italia: tendenze storiche, biologia riproduttiva e fenologia. Avocetta, 30: 15-19.

Bordignon L., Brunelli M. \& Visceglia M., 2007 - Nuovi dati sulla nidificazione della Cicogna nera Ciconia nigra in Italia. Alula, XIV: 124-125.

Bordignon L., Gatti F. \& Chiozzi G., 2009 - Tentativo di nidificazione di Cicogna nera in Lombardia. Rivista italiana di Ornitologia, 79 (1): 60-63.

Brichetti P. e Fracasso G., 2003 - Ornitologia italiana. 1 Gaviidae Falconidae. Oasi Alberto Perdisa editore, Bologna.

Brunelli M., Montemaggiori A., Prola G. \& Sestieri L., 2014 - Prima nidificazione con successo della Cicogna nera Ciconia nigra in Lazio. Alula, XXI: 76-78.

Cano Alonso L. S., 2013 - Biologia y conservacion de the Ciguena negra Ciconia nigra en la Peninsula Iberica. PhD dissertation, Universidad Complutense de Madrid.

Cano Alonso L. S., \& Fernandez M., 2003 - The Black Stork Ciconia nigra in Madrid region: status, population changes and reproduction. Aves, 40: 38-43.

Cheylan G., 1981 - Introduction. Rapaces mediterranees. Parc Naturel Regional de Corse. Centre Recherche Ornithologique de Provence, Aix en Provence: 2-3.

Cramp S. \& Simmons K. E. L. (eds.), 1977 - The Birds of the Western Paleartic. Vol. 1. Oxford University Press, Oxford.

Czuchnowski R., Kurowski M. \& Profus P., 2003 - The population of the Black Stork in Radom province, Poland (1981-1995). ADENEX, 68.

del Hoyo J., Elliott A., \& Christie D. A., 1992 - Handbook of the Birds of the World. Vol. 1. Ostrich to Ducks. Lynx Ed., Barcelona.

Denis P. \& Brossault P., 2016 - Historique de la population nicheuse de Cigogne noire en France. Ornithos, Hors-série 1: 61-64.

Dornbusch G. \& Dornbusch M., 1996 - Bestandsentwicklung und Schutz des Schwarzstorchs (Ciconia nigra) in Sachsen - Anhalt. Vogel und Umwelt, 8: 287-93.

Dzyubenko N. \& Bokotey A., 2011 - The present status of the breeding population of the Black Stork (Ciconia nigra) in Ukraine. Abstract's book of the $8^{\text {th }}$ Conference of the European Ornithologists' Union 27-30 August 2011, Riga: 116.

Gendre N., Brossault P. \& Chapalain F., 2014 - Etude et Protection de la Cigogne noire en France. Bilan de l'année 2014. ONF-LPO eds.

Hormann M., 1999 - Bestandssituation und entwicklung des Schwarzstorchs (Ciconia nigra) in Europe und Hinweise zum Monitoring. Vogel und Umwelt, 10: 85-98.

Hormann M. \& Richarz K., 1996. - Schutzstrategien und Bestandsentwicklung des Schwarzstorchs (Ciconia nigra) in Hessen und Rheinland - Pfalz - Ergebnisse einer Fachtagung. Vogel und Umwelt, 8: 275-286.
Jans M. \& Lorge P., 2003 - La cigogne noire au Grand-duchè de Luxembourg. Aves, 40: 17-20.

Janssen G., Hormann M. \& Rohde C., 2004 - Der Schwarzstorch. Die Neue Brehm-Bücherei, 468.

Kalocsa B. \& Tamas E. A., 2003 - Status of the Black Stork Ciconia nigra in Hungary in the year 2000. Aves, 43: 45-49.

Kalocsa B. \& Tamas E. A., 2016 - Statut de population et de conservation de la Cigogne noire en Hongrie. Ornithos, Hors-série 1: $38-41$.

Lhomus A. \& Sellis U., 2003 - Nest trees: a limiting factor for the Black Stork (Ciconia nigra) population in Estonia. Aves, 40: 8491.

Lorge P., 2016 - La Cigogne noire au Grand-Duché de Luxembourg. Ornithos, Hors-série 1: 42-43.

Mordente F., Rocca G., Salerno S. \& Serroni P., 1998. Cigogne noire, Ciconia nigra, nidificatrice en Calabre (Italie du Sud). Alauda, 66: 321-323.

Pannekoek J. \& Van Strien A., 2013 - Trends \& Indices for Monitoring data. Statistics Netherlands ed.

Peronace V., Cecere J. G., Gustin M. \& Rondini C., 2012 - Lista Rossa 2011 degli Uccelli nidificanti in Italia. Avocetta, 36: 1158.

Petrov T., Iankov P., Profirov L., Stoinov E. \& Avramov S., 1995 The Black Stork in Bulgaria: status, trends an conservation. II International Conference on the black stork, Trujillo (Spain): 40.

Petrov N., Iankov P. \& Georgiev D., 2006 - Recent status and changes in the breeding population of the black stork Ciconia nigra in Bulgaria. Biota, 7: 77-82.

Pojer F., 2003 - Black Stork Ciconia nigra in the Czech Republic. Present Status and Conservation. Aves, 40: 20-21.

Pojer F. \& Vo Itechovska E., 2016 - La Cigogne noire en République tchèque: état de la population et conservation. Orntihos, Horssérie 1: 36-37.

Sellis U., 2000 - Will the Black Stork remain to breed in Estonia? Hirundo, 13: 19-30.

Snow D. W. \& Perrins C. M., 1998 - The Birds of Western Palearctic. Concise Edition. Vol. 1. Oxford University Press, Oxford.

Strazds M., 2011 - Conservation ecology of the Black Stork in Latvia. $\mathrm{PhD}$ disseration. Facultad de Biología, Universidad de Letonia.

Strenna L., Chapalain F., Brossault P. \& Gendre N., 2016 - Relecture des Cigognes noires baguées en France: bilan 1995-2011. Orntihos, Hors-série 1: 44-56.

Tamas E. A., 2012 - Breeding and migration of the Black Stork ( $\mathrm{Ci}$ conia nigra), with special regard to a Central European population and the impact of hydro-meteorological factors and wetland status. PhD disseration, University of Debrecen.

von Puhringer N., 2007 - Bestandserfassung des Schwarzstorches (Ciconia nigra) in oberösterreich brutbiologie und aktuelle situation der jahre 2006/2007. Vogelkdl. Nachr. OÖ., 15: 85-126.

Zielinski P., Profus P. \& Czuchnowski R., 2011 - Present situation of the Black Stork (Ciconia nigra) in Poland. Abstract's book of the $8^{\text {th }}$ Conference of the European Ornithologists' Union 27-30 August 2011, Riga: 418. 